\title{
VARIATION OF ORGANIC MATTER CONCENTRATIONS IN STREAM WATER IN MANURE FERTILIZED FIELDS
}

\author{
Stefanija Misevičienè \\ Aleksandras Stulginskis University, Lithuania \\ stefanija.miseviciene@asu.lt
}

\begin{abstract}
The article provides the research data on the variation of organic matter in the Jaugila Stream, which flows through drained fields fertilized with organic fertilizers. The aim of the research was to determine the effect of manure application in drainage basin to the changes of organic matter concentration in the Jaugila Stream.

Water samples for chemical analysis were taken once a month from the drainage water and the river. The samples from the river were taken upsream and downstream manure fertilized fields and the drainage water - from the outlets of the drainage system, which drains the fertilized area. Water analysis was performed by the Analytical Laboratory of Chemical Analysis of the ASU Water Research Institute. BOD 7 was determined by titrometric method.

The research has shown that a greater impact on the increase of $\mathrm{BOD}_{7}$ concentrations in the Jaugila Stream was due to the stream water, saturated with the organic matter, flowing from the upstream areas, rather than the drainage water flowing into this stream from manure fertilized area. The assessment of $\mathrm{BOD}_{7}$ concentrations according to the water quality requirements for surface waters determined that in most cases the water of the Jaugila Stream, both in above and below fertilized areas, was in a very good or good ecological status. The impact of manure fertilized areas on the organic matter concentration in the stream was determined to be minimal, as the statistical analysis of the data has shown that the difference between $\mathrm{BOD}_{7}$ concentrations above and below fertilized areas is negligible.
\end{abstract}

Key words: $\mathrm{BOD}_{7}$, concentration, drainage water, ecological status, surface water.

\section{Introduction}

A diffuse source agricultural pollution has a big impact on the status of water bodies (Ballantine \& Davies-Colley, 2014; Ilijevič et al., 2012). Due to the intensive development of agricultural activity in the Middle Lithuanian Lowland, where the most fertile soils of Lithuania are located, the water quality of streams in this region is greatly impaired. Especially where livestock is being developed (Wen et al., 2017). Organic fertilizers formed on the farm are spread out in the fields, but due to unfavourable meteorological conditions some of them are washed out into surface waters. A decreasing trend of water pollution in streams has recently been observed. According to the 2011 - 2017 National Environmental Monitoring data, $51 \%$ of rivers and $40 \%$ of lakes in Lithuania still do not meet the criteria for good ecological status (Valstybinio..., 2016). From the organic pollution point of view, the river water quality was determined to be slightly better, except for the Sesupe sub-basin, where high concentrations of biochemical oxygen consumption over 7 days (hereinafter - BDS $_{7}$ ) were identified, which correspond to a very bad and bad water quality (2016 m. upių..., 2016).

The Water Framework Directive obliges the EU Member States to take the necessary measures to prevent the deterioration of the status of surface and groundwater bodies and to achieve their good status by 2015 at the latest. However, if failing to do so, this term is proposed to be extended until 2021 or even until 2027 (Dèl vandenų..., 2017). The analysis of the status of the surface water bodies in Lithuania has shown that it is improving, but not enough. On the 1st February 2017, the Government of the Republic of Lithuania has adopted a resolution 'On the Approval of the Program for the Development of the Water Area During 2017 - 2023' which states that the focus will be on prevention of water pollution during the mentioned period. One of the tasks is to reduce the pollution of water bodies from agricultural pollution sources.

Diffuse source pollution is greatly increased by the livestock farms, which produce large amounts of manure. To ensure a proper use of nutrients from the organic fertilizer, fertilization plans are being developed. However, the occurring natural processes are not always manageable; therefore, there are cases when nutrients are washed out of the soil. The fact that organic pollutants are in surface water can be judged by biochemical oxygen consumption concentrations: when they are high, it can be claimed that the water body is contaminated (Simon et al., 2011). In manure fertilized fields when the drainage water is lacking oxygen, the concentration of organic matter increases (Malik, 2016). In drained cultivated areas, such water quickly reaches the surface water bodies by drainage and contaminates them.

The aim of the research was to determine the effect of manure fertilized fields on the changes of organic matter in the Jaugila Stream.

\section{Materials and Methods}

Drainage and surface water quality research was conducted during 2008 - 2012 (Figure 1). The area selected for research is fertilized by cattle manure, 


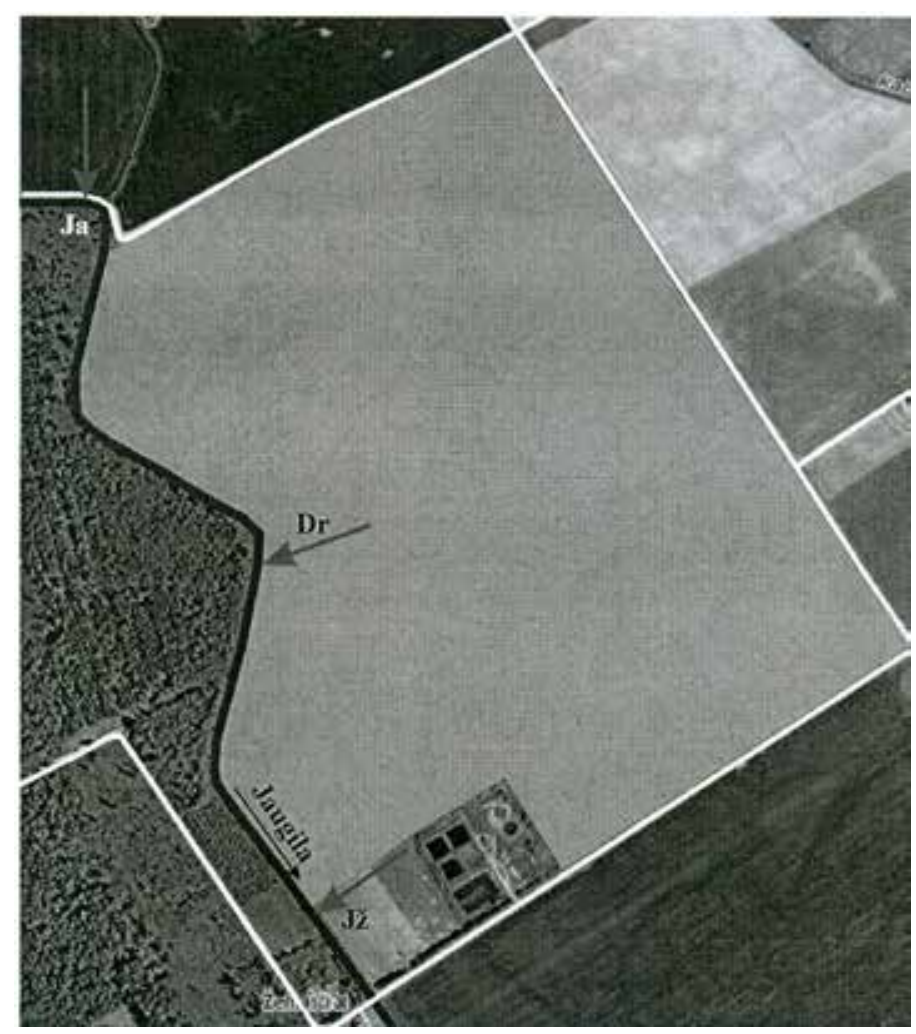

Figure. 1. The scheme of research object. Ja - Jaugila stream's water sampling point above manure fertilized area, Jž - Jaugila stream's water sampling point below manure fertilized area, $\mathrm{Dr}$ - subsurface drainage outlet.

making from livestock farm (629 conditional livestock). Drainage water flows into the stream via drainage outlet. The area of the drainage system is 27.1 ha. Jaugila is a stream of Nevezis River basin flowing through cultivated land. It is the left tributary of the Smilga Stream. The length of the sream $33.2 \mathrm{~km}$, the basin area $-61.8 \mathrm{~km}^{2}$. The Jaugila Stream valley from its springs to $28.9 \mathrm{~km}$ is regulated. It is assigned to the risk group of water bodies due to water quality and straightening (Aplinkos..., 2010).

To fertilize the research fields, litter-free manure of cattle was used, and the fertilization took place in spring. According to the fertilizing value of manure, the following contents of total nitrogen passed into manure-fertilized fields each year: $2008-169 \mathrm{~kg}$ ha-1, 2009 - $168 \mathrm{~kg} \mathrm{ha}^{-1}$; 2010 - $169 \mathrm{~kg} \mathrm{ha}^{-1}, 2011$ $169 \mathrm{~kg} \mathrm{ha}^{-1}, 2012$ - $170 \mathrm{~kg} \mathrm{ha}^{-1}$. $\mathrm{P}_{\text {tola }}$ passed into the fertilized fields as follows: $2008-23 \mathrm{~kg} \mathrm{ha}^{-1}$, 2009 - $27 \mathrm{~kg} \mathrm{ha}^{-1} ; 2010$ - $28 \mathrm{~kg} \mathrm{ha}^{-1}, 2011$ - $34 \mathrm{~kg} \mathrm{ha}^{-1}$, 2012 - $36 \mathrm{~kg} \mathrm{ha}^{-1}$. Potassium passed into the fertilized fields as follows: $2008-239 \mathrm{~kg} \mathrm{ha}^{-1}, 2009-$ $197 \mathrm{~kg} \mathrm{ha}^{-1} ; 2010$ - $202 \mathrm{~kg} \mathrm{ha}^{-1}, 2011$ - $260 \mathrm{~kg} \mathrm{ha}^{-1}$, $2012-223 \mathrm{~kg} \mathrm{ha}^{-1}$. Maize for cattle forage was grown in experimental fields.

To determine the rainfall and air temperature, data from Dotnuva Meteorology Station were used (Table 1).
Precipitation had distributed unevenly in the object during the research period. During the whole research period, the precipitation amount was higher than the climate normals from 1\% in 2008 and 2001 to 30\% in 2009. Precipitation, $28 \%$ over the climate normals, has fallen in 2010 and 2012. The average air temperature, higher than the climate normals, was in 2008, 2009 and 2011, $+1.5,+0.2$ and +0.9 respectively, and lower than the climate normals in 2010 and 2012, -0.8 and $-0.3^{\circ} \mathrm{C}$ respectively.

During the wet years, 2009 and 2012, the drainage operated throughout the year, except in 2010, when, due to a very low average air tempetature in January (-10.7), February (-4.4), and March (-0.2), there was no drainage runoff. During the dry year in 2008, the drainage runoff during May - October months did not form due to $47.8 \mathrm{~mm}$ lower precipitation amount and $0.4^{\circ} \mathrm{C}$ higher air temperature compared to the climate normals. In 2011, a dry year as well, the drainage operated throughout the year (during summer-autumn time the precipitation amount was $30.7 \mathrm{~mm}$ higher than the climate normals), except February when the average air temperature was $-7.7^{\circ} \mathrm{C}$ (the climate normals: $-3.3^{\circ} \mathrm{C}$ ).

Water samples for chemical analysis were taken once a month from the subsurface drainage system which is installed in the fertilized area and the 
Meteorological conditions of the study periods

\begin{tabular}{|l|c|c|c|c|c|}
\hline \multirow{2}{*}{\multicolumn{1}{|c|}{ Indices }} & \multicolumn{5}{c|}{ Year } \\
\cline { 2 - 6 } & 2008 & 2009 & 2010 & 2011 & 2012 \\
\hline Precipitation, mm & 574 & 736 & 722 & 574 & 723 \\
\hline$\%$ of the climate normals & 101 & 130 & 128 & 101 & 128 \\
\hline Average air temperature, ${ }^{\circ} \mathrm{C}$ & 8.5 & 7.2 & 6.2 & 7.9 & 6.7 \\
\hline${\text { Deviation from the climate normals, }{ }^{\circ} \mathrm{C}}^{*}$ & +1.5 & +0.2 & -0.8 & +0.9 & -0.3 \\
\hline
\end{tabular}

Note. Climate normals in Dotnuva: annual precipitation amount $-566 \mathrm{~mm}$, average yearly air temperature $7.0^{\circ} \mathrm{C}$.

stream. The samples from the stream were taken at the points situated above and below the fields under fertilization. The drainage water samples were taken from the drainage outlet. Water analysis, according to the methodology provided in literature (Unifikuoti..., 1994), was performed by the accredited Analytical Laboratory of Chemical Analysis of the ASU Water Research Institute. BOD 7 was determined by titrometric method (Vincler), with the difference in oxygen level being calculated after seven days of incubation.

The surface water bodies' quality is currently assessed according to "The Surface Water Bodies' State Evaluation Methodology" approved by the Minister of Environment of the Republic of Lithuania (Paviršinių..., 2010). According to this methodology, the ecological state of rivers is divided into 5 classes from a very good $\left(\mathrm{BOD}_{7}<2.3\right)$, good $\left(\mathrm{BOD}_{7}-2.3-\right.$
3.3), moderate - $\left(\mathrm{BOD}_{7}-3.31\right.$ - 5.0), poor $\left(\mathrm{BOD}_{7}-\right.$ $5.01-7.0)$ and a very bad state $-\mathrm{BOD}_{7}>7 \mathrm{mg} \mathrm{O}_{2} \mathrm{l}^{-1}$.

The composition of manure was identified from one extract prepared by burning with concentrated sulphuric acid $\left(\mathrm{H}_{2} \mathrm{SO}_{4}\right)$ and selenium (Se) catalyst. Nitrogen was identified by Kjeldal method, phosphorus - by molybdic method.

Mathematical and statistical analysis of the data was performed using the computer programs MS Excel 2010 and Statistica v.5.

\section{Results and Discussion}

During the research period the concentrations of organic matter in Jaugila stream above fertilized area (Ja) changed from 0.74 to 11.1 , and below it (Jž) from 0.9 to $11.6 \mathrm{mg} \mathrm{O}_{2} \mathrm{l}^{-1}$ (Figure 2).

It was determined that in most cases the water of the Jaugila Stream, both in above and below fertilized

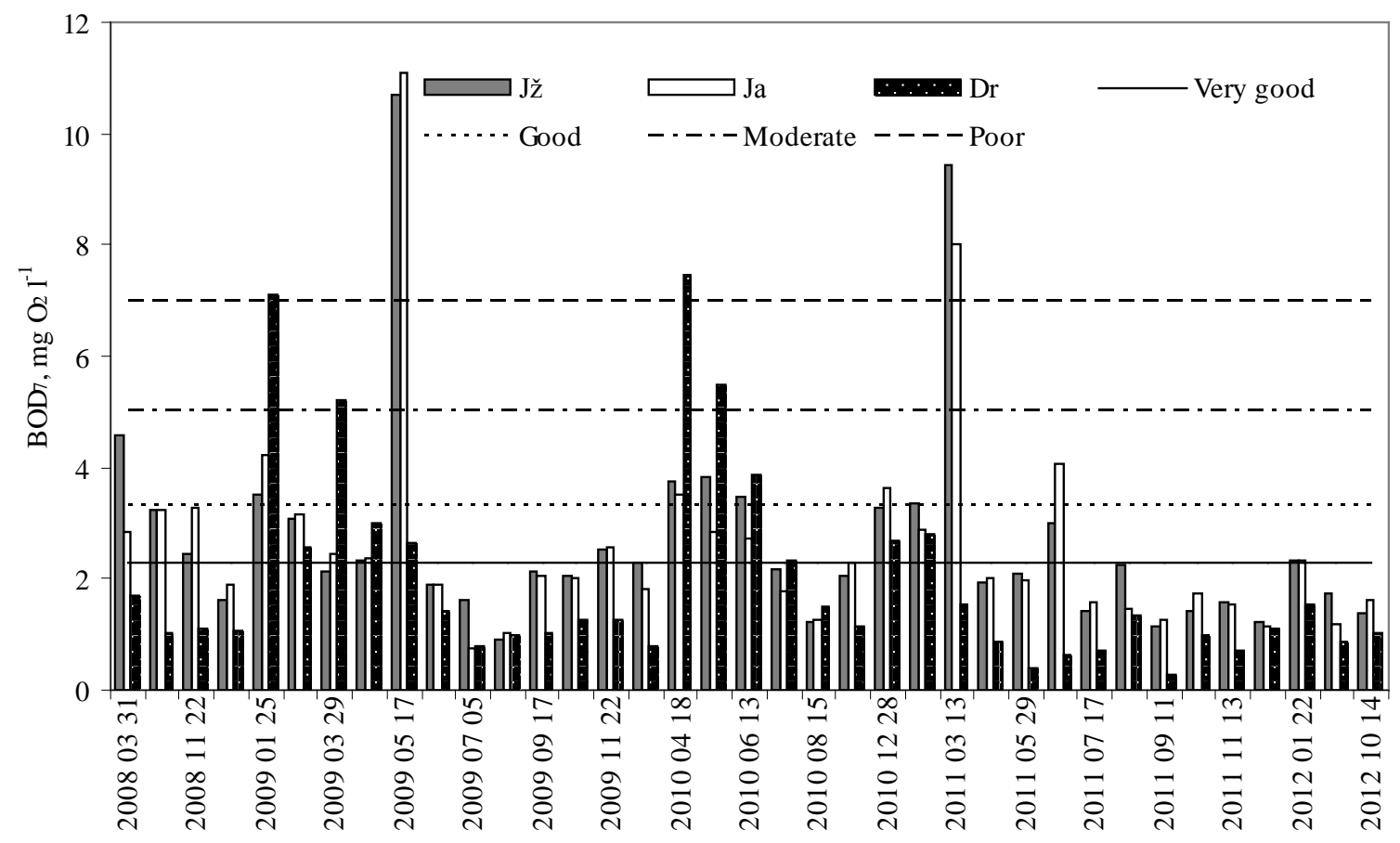

Figure 2. Variation of $\mathrm{BDS}_{7}$ concentrations in the Jaugila Stream above (Ja) and below (Jž) fertilized areas as well as from the drainage system (Dr). 
The impact of $\mathrm{BOD}_{7}$ concentrations of drainage and water flowing from above fertilized areas to Jaugila Stream water quality below fertilized areas

\begin{tabular}{|c|c|c|c|c|c|}
\hline Indices & Equation & $\mathrm{n}$ & $\mathrm{r}$ & $\mathrm{t}_{\text {theor.95\% }}$ & $\mathrm{t}_{\text {fact. }}$ \\
\hline $\mathrm{Ja}$ & $\mathrm{y}=0.0211 \mathrm{x}_{1}{ }^{2}+0.6946 \mathrm{x}_{1}+0.4987$ & 37 & 0.96 & 2.03 & 73.39 \\
\hline $\mathrm{Dr}$ & $\mathrm{y}=-0.1495 \mathrm{x}_{2}{ }^{2}+1.8969 \mathrm{x}_{2}-1.5443$ & 37 & 0.56 & 2.03 & 4.93 \\
\hline
\end{tabular}

Note: $y-\mathrm{BOD}_{7}$ concentration in the water of Jaugila Stream in the point below fertilized areas (Jž), $\mathrm{mg} \mathrm{O}_{2} \mathrm{l}^{-1} ; \mathrm{x}_{1}-\mathrm{BOD}_{7}$ concentration in the water of Jaugila Stream in the point above fertilized areas (Ja), $\mathrm{mg} \mathrm{O}_{2} \mathrm{l}^{-1} ; \mathrm{x}_{2}-\mathrm{BOD}_{7}$ concentration in drainage water, flowing into the Jaugila Stream from the fertilized areas (Dr), $\mathrm{mg} \mathrm{O}_{2} \mathrm{l}^{-1} ; \mathrm{n}$ - sample data points, $\mathrm{r}-$ sample correlation coefficient, $\mathrm{t}_{\text {fact. }}$ - calculated Student's t-test, $\mathrm{t}_{\text {heor.95\% }}$ - theoretical $95 \%$ probability of Student's $\mathrm{t}$-test $=2.03$; relationship is significant when $\mathrm{t}_{\text {theor.95\% }}<\mathrm{t}_{\text {fact. }}$.

areas, according to $\mathrm{BOD}_{7}$, concentrations correspond to a very good and good ecological status. There were only two cases when the $\mathrm{BOD}_{7}$ concentrations reached the limit of a very bad ecological status. The average concentrations of organic matter during the research period in the Jaugila Stream were $2.64 \mathrm{O}_{2}$ $\mathrm{l}^{-1}$ in the point above-fertilized area and $2.73 \mathrm{mg} \mathrm{O}_{2}$ $\mathrm{l}^{-1}$ in the point below fertilized area. However, the statistical data analysis has shown that the difference between these concentrations is negligible $\left(\mathrm{t}_{\mathrm{fact}}=0.22\right.$ $<\mathrm{t}_{\text {theor.95\% }}=2.0, \mathrm{n}=37$ ).

In Lithuania, the requirements for drainage water quality from manure fertilized areas according to $\mathrm{BOD}_{7}$ have not been established. Therefore, $\mathrm{BOD}_{7}$ concentrations in drainage water were compared to the requirements for the quality of surface water. The analysis showed that the drainage water corresponded to a very good and good ecological status, except in 4 cases when the water quality was found to be in a very bad 7.12 (25.01.2009) and $7.48 \mathrm{mg} \mathrm{O}_{2} \mathrm{l}^{-1}$ (18.04.2010) as well as poor 5.23 (29.03.2009) and $5.49 \mathrm{mg} \mathrm{O}_{2} \mathrm{l}^{-1}$ (09.05.2010) ecological status.

It was found that a great impact on $\mathrm{BOD}_{7}$ concentrations in the stream below fertilized area was due to the water flowing from the upstream area $\left(\mathrm{r}=0.96 ; \mathrm{t}_{\text {fact }}=73.39>\mathrm{t}_{\text {theor.95\% }}=2.03 ; \mathrm{n}=37\right)$ as well as the drainage water flowing into this stream from the fertilized area $\left(\mathrm{r}=0.56 ; \mathrm{t}_{\text {fact }}=4.93>\mathrm{F}_{\text {theor.95\% }}=2.03 ; \mathrm{n}=37\right)$. The following equations were derived (Table 2):

Water temperature has a big impact on the increase in $\mathrm{BOD}_{7}$ concentrations. The warmer the water in the stream, the higher the observed concentrations $\left(\mathrm{r}=0.45 ; \mathrm{t}_{\text {fact }}=3.39>\mathrm{t}_{\text {theor. } 95 \%}=2.0 ; \mathrm{n}=37\right)$ :

$$
y=0.2668 x+0.8486
$$

here $\mathrm{y}-\mathrm{BOD}_{7}$ concentration in the Jaugila Stream water, below fertilized area ( $\mathrm{Jž}), \mathrm{mg} \mathrm{O}_{2} \mathrm{l}^{-1}$, $\mathrm{X}$ - water temperature in the Jaugila Stream water, below fertilized area $(\mathrm{Jž}),{ }^{\circ} \mathrm{C}$.

Figure 3 shows that the maximum concentration deviations from the mean value of $\mathrm{BOD}_{7}$ concentration were observed in autumn, summer and spring, and in winter these deviations were small. This means that, as the air was getting warmer, the concentrations of organic matter in streams increased due to the influence of the temperature, which creates conditions for different physical, chemical, biochemical and biological processes in the water (Tilickis, 2005). The $\mathrm{BOD}_{7}$ concentrations in streams' water begin to increase when water temperature reaches more than $5{ }^{\circ} \mathrm{C}$ (Rudzianskaite, 2009).

So, the seasonality is characteristic to the variations in $\mathrm{BOD}_{7}$ concentrations in the Jaugila Stream. The highest average values were observed during spring. This is usually influenced by the concentration of suspended solids due to the increased water flow (Ebise et al., 2003). In spring the water flows are the greatest due to the snow melting, therefore the concentrations of organic matter increase. However, they are lower than those from urbanized areas (Ghane et al., 2016). In the point above fertilized areas ( $\mathrm{Ja}$ ) they were 3.8 and below them (Jž) - $4.4 \mathrm{mg} \mathrm{O}_{2} \mathrm{l}^{-1}$. Research data shows that higher average concentrations of organic matter in spring, summer and autumn were found in the Jaugila Stream in the point below fertilized area, 4.4, 3.5 and $3.0 \mathrm{mg} \mathrm{O}_{2} \mathrm{l}^{-1}$ respectively. Only during the winter period they were $0.1 \mathrm{mg} \mathrm{O}_{2} \mathrm{l}^{-1}$ lower than above fertilized area. Higher average $\mathrm{BOD}_{7}$ concentrations in drainage water were observed in spring and winter, 2.94 and $2.5 \mathrm{mg} \mathrm{O}_{2} \mathrm{l}^{-1}$ respectively. In summer and autumn, they were the lowest and varied from 1.5 to $1.0 \mathrm{mg} \mathrm{O}_{2} \mathrm{l}^{-1}$ (Figure 3).

A statistical analysis of each season was carried out to determine the effect of water flowing from the above fertilized areas and drainage water inflowing from the areas fertilized with organic fertilizer on the water of the Jaugila Stream in the below fertilized areas. Undoubtedly, these factors had a significant impact on the river's water, as the established relationships were very strong. The following relationships were determined during the spring, summer, autumn and winter seasons $\left(\mathrm{r}=0.97 ; \quad \mathrm{F}_{\text {fact }}=58.99>\mathrm{F}_{\text {theor. } 95 \%}=4.7\right.$; $\mathrm{n}=10) ; \quad\left(\mathrm{r}=0.89 ; \quad \mathrm{F}_{\text {fact }}=14.63>\mathrm{F}_{\text {theor. } 95 \%}=4.7 ; \quad \mathrm{n}=10\right)$; $\left(\mathrm{r}=0.92 ; \quad \mathrm{F}_{\text {fact }}=17.77>\mathrm{F}_{\text {theor. } 95 \%}=5.1 ; \quad \mathrm{n}=9\right) ; \quad(\mathrm{r}=0.93$; 


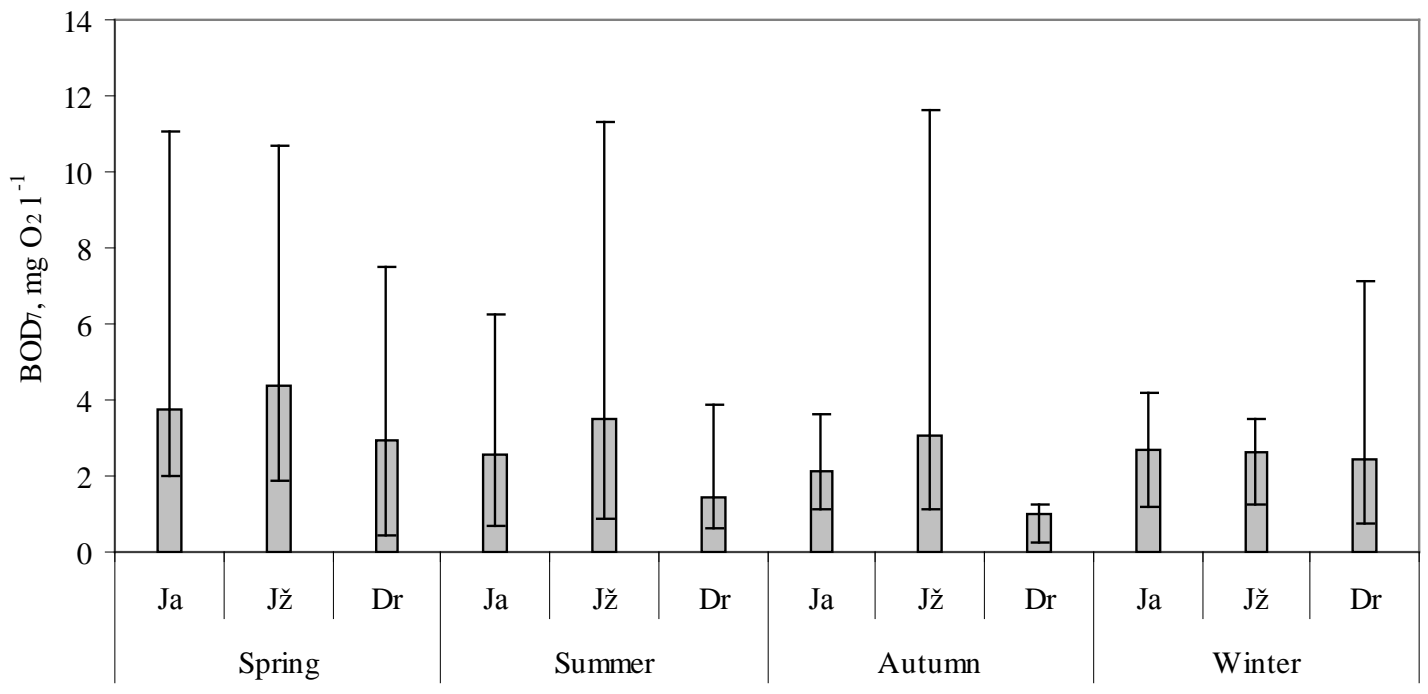

Figure 3. Seasonal variation of $\mathrm{BOD}_{7}$ concentrations in the Jaugila Stream and drainage water.

$\mathrm{F}_{\text {fact }}=16.39>\mathrm{F}_{\text {theor.95\% }}=5.8 ; \quad \mathrm{n}=8$ ) respectively, and dependencies:

In spring $z=0.436295+0.999243 x_{1}-0.025294 x_{2}$;

In summer $z=0.469562+0.563643 x_{1}+0.345824 x_{2}$;

In autumn $z=0.245256+0.565841 x_{1}+0.475830 x_{2}$;

In winter $z=0.362815+0.938675 x_{1}-0.099747 x_{2}$.

here $\mathrm{z}-\mathrm{BOD}_{7}$ concentration in the water of Jaugila Stream in the point below fertilized areas ( Jž), $\mathrm{mg} \mathrm{O}_{2} \mathrm{l}^{-1}$, $\mathrm{X}_{1}-\mathrm{BOD}_{7}$ concentration in the water of Jaugila Stream in the point above fertilized areas (Ja), $\mathrm{mg} \mathrm{O}_{2} \mathrm{l}^{-1}$, $\mathrm{x}_{2}-\mathrm{BOD}_{7}$ concentration in drainage water, flowing into the Jaugila Stream from the fertilized areas (Dr), $\mathrm{mg} \mathrm{O}_{2} \mathrm{l}^{-1}$.

Partial correlation showed that during the spring season, the increase in the $\mathrm{BOD}_{7}$ concentrations in the water of Jaugila Stream below fertilized areas was due to the water coming from the above areas $\left(r_{1}=0.97\right)$, and the drainage water had no impact at all $\left(\mathrm{r}_{2}=-0.08\right)$. During the summer and autumn seasons, the increase in organic matter in the stream was influenced both by the water coming from the above areas and drainage water, $\left(r_{1}=0.84\right),\left(r_{2}=0.69\right)$ and $\left(r_{1}=0.82\right),\left(r_{2}=0.52\right)$, respectively. During the winter season, the increase in the organic matter concentrations below fertilized areas was determined by water coming from the above areas $\left(\mathrm{r}_{1}=0.85\right)$, while drainage water reduced these concentrations $\left(r_{2}=-0.33\right)$.

\section{Conclusions}

1. A greater impact on the water quality of the Jaugila Stream below the fertilized area was from the water coming from the above areas $(r=0.96)$ than from the drainage water from the field fertilized with organic fertilizer $(\mathrm{r}=0.56)$.

2. It was found that drainage water was increasing the concentrations of $\mathrm{BOD}_{7}$ in river water in the summer and autumn seasons, $\left(r_{2}=0.69\right.$ and $\left(r_{2}=0.52\right)$ respectively. During the winter season it was decreasing them $\left(\mathrm{r}_{2}=-0.33\right)$ and during spring - it had no effect $\left(r_{2}=0.08\right)$.

3. Impact of the manure fertilized areas on the Jaugila Stream water pollution with organic matter was minimal, as the difference between the concentrations of $\mathrm{BOD}_{7}$ in the points above and below fertilized areas was not significant $\left(\mathrm{t}_{\text {fact }}=0.22\right.$ $<\mathrm{t}_{\text {theor.95\% }}=2.0, \mathrm{n}=37$ ).

4. The assessment of the concentrations of $\mathrm{BOD}_{7}$ according to the water quality requirements for surface waters showed that in most cases the water of the Jaugila Stream, both in upstream and downstream manure fertilized fields, was in a very good and good ecological status.

\section{References}

1. Aplinkos apsaugos agentūra. Informacinis portalas www.aplinka.lt. Žemèlapiai sudaryti 2010 metais. (Environmental Protection Agency. Information portal www.aplinka.lt. Mapping created in 2010) Retrieved February 18, 2018, from: http://vanduo.gamta.lt/cms/index?rubricId=17a05652-2666-4bcc8cdd-1dd501f7c569. (in Lithuanian).

2. Ballantine, D.J., \& Davies-Colley, R.J. (2014). Water quality trends in New Zealand rivers: $1989-2009$. Environ Monit Assess, 186, 1939-1950. DOI: 10.1007/s10661-013-3508-5. 
3. Dèl vandenų srities plètros 2017-2023 metų programos patvirtinimo $2017 \mathrm{~m}$. vasario $1 \mathrm{~d}$. nutarimas $\mathrm{Nr}$. 88. (On the Approval of the Program for the Development of the Water Area 2017-2023, 1st February 2017 Resolution No. 88.) Vilnius. Lietuvos respublikos vyriausybė, Vilnius, TAR, 2017-02-09, Nr. 2348. (in Lithuanian).

4. Ilijevič, K., Gržetič, I., Živadinovič, I., \& Popovič, A. (2012). Long-term seasonal changes of the Danube River eco-chemical status in the regionon of Serbia. Environ Monit Assess 184, 2805-2828. DOI: 10.1007/ s10661-011-2153-0.

5. Inoue, T., Ebise, S, Matsui, Y., \& Matsushita, T. (2003). Estimation of organic pollutant and nutrient loadings in a rural river. In Diffuse Pollution and Basin Management. Proceedings of the 7th International Specialised IWA Conference, 17-21 August 2003. (pp. 5-19). Dublin, Ireland.

6. Ghane, E., Ranaivoson, A.Z., Feyereisen, G.W., Rosen, C.J., \& Moncrief, J.F. (2016). Comparison of contaminant transport in agricultural drainage water and urban stormwater runoff. PLoS One, 11(12): e0167834. DOI: 10.1371/journal.pone.0167834.

7. Malik, R. (2016). Predictions of BOD-DO Concentration in River/Stream: A Mathematical Approch. In Special Issue on International Journal of Recent Advances in Engineering \& Technology (IJRAET) V-4 I-2 For National Conference on Recent Innovations in Science, Technology \& Management (NCRISTM) ISSN (Online): 2347-2812, Gurgaon Institute of Technology and Management, Gurgaon 26th to 27th February 2016.

8. Paviršiniu vandens telkiniu büklès nustatymo metodika. (Surface water bodies’ state evaluation methodology). (2010). Valstybės Žinios, No. 29-1363. (in Lithuanian).

9. Rudzianskaitè, A. (2009). Organinių medžiagų koncentracijos kaita Nevėžio upés aukštupyje. (The change of organic matter concentration in the upper reaches of Nevėžis). Vandens ūkio inžinerija, 35(55), 82-88. (in Lithuanian).

10. Simon, F.X., Penru, Y., Guastalli, A.R., Llorens, J., \& Baig, S. (2011). Improvement of the analysis of the biochemical oxygen demand (BOD) of Mediterranean seawater by seeding control. Talanta, 85:527-532. DOI: 10.1016/j.talanta.2011.04.032.

11. Tilickis, B. (2005). Vandens cheminès sudèties kaita Lietuvos baseinuose (Water chemical composition alternation in Lihuanian cathments) Klaipeda: Klaipedos universiteto leidykla. (in Lithuanian).

12. Unifikuoti nuotekų ir paviršinio vandens kokybès tyrimų metodai (Unified Study Methods of Wastewater and Surface Water Quality) (1994). Vilnius: AAM leidybos biuras. (in Lithuanian).

13. Valstybinio upių monitoringo duomenys. (National river monitoring data) (2016). Aplinkos apsaugos agentūra. Retrieved January 10, 2018, from: http://vanduo.gamta.lt/cms/index?rubricId=6adeeb1d-c90249ab-81bb-d64b8bccefdd. (in Lithuanian).

14. Wen, Y., Schoups, G., \& van de Giesen, N. (2017). Organic pollution of rivers: Combined threats of urbanization, livestock farming and global climate change. Sci Rep. 7: 43289. DOI: 10.1038/srep43289.

15. $2016 \mathrm{~m}$. upių vandens kokybė pagal atskirus rodiklius. (River water quality according to different indicators 2016) Aplinkos apsaugos agentūra. (2016). Retrieved March 2, 2018, from: https://www.arcgis.com/apps/ MapSeries/index.html?appid=c7d22e22f58247b29158c605fef08606. (in Lithuanian). 